\title{
Metabolism of Triphenylmethane Colors (III)
}

\author{
Comparison of Tissue Distribution and Biliary Excretion for ${ }^{3} \mathrm{H}-B e n z y l$ \\ Violet 4B and ${ }^{3}$ H-Fast Green FCF (Food Green No. 3) in Rats
}

(Received July 11, 1978)

Ken-ichiro Minegishi, Kazushige Morimoto and Tsutomu Yamaha

(National Institute of Hygienic Sciences: 18-1, Kamiyama

1-chome, Setagaya-ku, Tokyo)

\begin{abstract}
Distribution and biliary excretion of Benzyl Violet 4B and Fast Green FCF were compared in female Sprague-Dawley rats after an oral administration of the ${ }^{3} \mathrm{H}$-labeled compounds.

The levels of Benzyl Violet 4B distributed in the plasma, ear, abdominal skin and abdominal muscle were higher than those of Fast Green FCF. The cumulative amounts of Benzyl Violet 4B and Fast Green FCF excreted in the bile were 4.26 and $3.81 \%$ of the dose by $24 \mathrm{hr}$, respectively. The biological half-lives for Benzyl Violet $4 \mathrm{~B}$ in the above tissues were longer than those for Fast Green FCF.
\end{abstract}

\section{Introduction}

Since Hess and Fitzugh ${ }^{1)}$ demonstrated that many triphenylmethane colors administered orally to rats were poorly absorbed and mostly excreted in feces, any special attention has not be paied for the metabolism of these colors except for the pharmacokinetical studies reported by Iga et al. ${ }^{2)}$

However, recently Uematsu and Miya ji ${ }^{3)}$ and Ikeda et al. ${ }^{4}$ ) described that female SpragueDawley rats fed a diet containing 5\% Benzyl Violet 4B for 12 months developed high incidences of mammary gland carcinoma and squamous cell carcinoma of the skin (mostly the ear-duct).

Therefore, in the previous paper, ${ }^{\mathrm{b})}$ we studied on the absorption, excretion and distribution of this color in adult male and female Wistar and Sprague-Dawley rats by the two-wavelength photometric method and showed that the halflives for the color in brain, abdominal muscle, abdominal skin and ear of Sprague-Dawley rats were significantly longer than those of Wistar rats after intravenous injection of the color.

In the present study, two kinds of tritiumlabeled triphenylmethane colors, Benzyl Violet 4B which was reported to be carcinogenic and Fast Green FCF which is not carcinogenic, were prepared and the distribution of these labeled colors in the plasma, abdominal skin including mammary gland, ear and abdominal muscle of female Sprague-Dawley rats were compared after oral administration of the colors.

\section{Materials and Methods}

\subsection{Preparation of labeled compound}

Benzyl Violet 4B (Acid Violet 6B, Color Index No. 42640, former Food Violet No. 1), manufactured by Hodogaya Chemical Industries Co., Ltd. (Lot No. H0086), which contained 94.1\% pure dye by spectrometry, and Fast Green FCF (Color Index No. 42053, FD and C Green No. 3), which was the National Institute of Hygienic Sciences Reference Standard (94\% pure dye), were used.

Both ${ }^{3} \mathrm{H}$-labeled colors were prepared by the platinum-catalyzed ${ }^{3} \mathrm{H}_{2}$ gas exposure technique in the Sinroihi Co., Ltd. In this technique, $698 \mathrm{mg}$ of Benzyl Violet 4B were exposed to 10 $\mathrm{Ci}$ of ${ }^{3} \mathrm{H}$ gas for 6 days. The crude sample was dissolved in 5\% sodium Bicarbonate solution and acidified immediately with $2 N$ hydrochloric acid to eliminate exchangeable ${ }^{3} \mathrm{H}$ atoms. The sample was adjusted to $\mathrm{pH} 7-8$ with $10 \%$ sodium hydroxide solution and extracted with tert-butanol. The tert-butanol layer was washed with distilled water five times. The sample solution was concentrated in vacuo, and the residue was redissolved in methanol. The solu- 
tion was evaporated to dryness in vacuo. About $50 \mathrm{mg}$ of the sample was passed through a column $(2.5 \times 35 \mathrm{~cm})$ packed with Avicel (microcrystalline cellulose, 150-220 mesh, Asahi Kasei Co., Ltd) and eluted with a mixture of acetonemethanol-water $(10: 1: 1)$. Each $2.5 \mathrm{ml}$ of the eluate was collected by a fraction collector (Toyo Roshi Co., Ltd). The main color fractions were combined and the combined solution was evaporated to dryness in vacuo. The sample was applied on the cellulose spot film (Tokyo Kasei Co., Ltd) and developed with a mixture of acetone-isoamyl alcohol-water $(6: 5: 5)$. ${ }^{3} \mathrm{H}$ Fast Green FCF was prepared by the same procedure as described above except for the extraction with tert-butanol from acidic medium. The specific activities of ${ }^{3} \mathrm{H}-\mathrm{Benzyl}$ Violet $4 \mathrm{~B}$ and ${ }^{3} \mathrm{H}$-Fast Green $\mathrm{FCF}$ were $54.7 \mu \mathrm{Ci} / \mathrm{mg}$ and $51.2 \mu \mathrm{Ci} / \mathrm{mg}$ respectively, and the radiochemical purities of both colors were found to be greater than $97 \%$ by thin-layer chromatography. The purified ${ }^{3} \mathrm{H}$-colors were dissolved in methanol and then gently evaporated to eliminate volatile radioactivity under a stream of nitrogen at room temperature before use. Both purified colors were stable in an aqueous solution $(0.2-0.4 \mu \mathrm{g} /$ $\mathrm{ml}$ ) at room temperature for 21 days.

\subsection{Animals}

Adult female Sprague-Dawley rats weighing between 230 and $280 \mathrm{~g}$ were used. Separate groups of animals received a single oral administration of $10 \mu$ moles $(7.34 \mathrm{mg}) / \mathrm{kg}$ of Benzyl Violet $4 \mathrm{~B}$ or $10 \mu$ moles $(8.09 \mathrm{mg}) / \mathrm{kg}$ of Fast Green FCF. Bile was collected from rats cannulated as described in the previous paper. ${ }^{5)}$

\subsection{Radioactivity measurement}

At the appropriate times, the animals were anaesthetised with pentobarbital $(40 \mathrm{mg} / \mathrm{kg}$, i.p.) and the blood was withdrawn by heart puncture. The animals were killed and the ear, abdominal skin, and abdominal muscle were removed and minced with scissors. An aliquot (80-100 mg or $0.1 \mathrm{ml}$ ) of the sample from tissue or plasma was transfered into a vial and then equal volume of methanol was added. To eliminate volatile radioactivity, the sample gently evaporated under a stream of nitrogen at room temperature and this procedure was repeated twice. After evaporation, the sample was made up to the original volume with water and then solubilized by the addition of $0.5 \mathrm{ml}$ of soluene 350 (Packard) with gentle shaking at $37^{\circ} \mathrm{C}$ overnight. To the solubilized sample, $10 \mathrm{ml}$ of a toluene scintillator containing $0.4 \% \quad 2.5$-diphenyloxazole (DPO) and $0.01 \%$ 1, 4-bis-(2-(5-phenyloxazolyl)) -benzene (POPOP) was added. As a scintillator for bile, $10 \mathrm{ml}$ of a mixture constituted of 2 vol. toluene, 2 vol. dioxane, 1 vol. methanol with $8 \%$ naphthalene, $0.4 \%$ DPO and $0.01 \%$ POPOP was used. The radioactivity was determined by an LSC-651 scintillation counter (Aloka).

\section{Results and Discussion}

Hess and Fitzhugh ${ }^{1)}$ indicated that many FD and $\mathrm{C}$ triphenylmethane colors administered

Table 1. Distribution of ${ }^{3} \mathrm{H}-B$ Benzyl Violet $4 \mathrm{~B}$ and ${ }^{3} \mathrm{H}$-Fast Green FCF in Plasma, Ear, Abdominal Skin and Abdominal Muscle (p.o.)

\begin{tabular}{|c|c|c|}
\hline \multirow{2}{*}{ Tissue } & $\begin{array}{l}{ }^{3} \mathrm{H}-\text {-Benzyl } \\
\text { Violet 4B }\end{array}$ & $\begin{array}{c}{ }^{3} \mathrm{H}-\mathrm{Fast} \text { Green } \\
\text { FCF }\end{array}$ \\
\hline & \multicolumn{2}{|c|}{$p$ moles dye equivalent/g or $\mathrm{ml}$} \\
\hline \multicolumn{3}{|l|}{ Plasma } \\
\hline $2(\mathrm{hr})$ & $532.8 \pm 39.00$ & $148.5 \pm 11.22^{\mathrm{c}}$ \\
\hline 7 & $195.9 \pm 37.50$ & $87.2 \pm 8.22^{\mathrm{d}}$ \\
\hline 15 & $102.7 \pm 13.09$ & $28.2 \pm 7.03^{\mathrm{c}}$ \\
\hline 24 & $68.7 \pm 8.98$ & $14.4 \pm 1.44^{\mathrm{c}}$ \\
\hline \multicolumn{3}{|l|}{ Ear } \\
\hline $2(\mathrm{hr})$ & $271.3 \pm 15.11^{\mathrm{a}}$ & $96.0 \pm 8.87^{\mathrm{c}}$ \\
\hline 7 & $182.8 \pm 19.85^{\mathrm{b}}$ & $92.2 \pm 9.18^{\mathrm{c}}$ \\
\hline 15 & $153.4 \pm 10.77^{\mathrm{a}}$ & $60.6 \pm 7.74^{c}$ \\
\hline 24 & $120.7 \pm 7.30^{\mathrm{b}}$ & $31.4 \pm 3.73^{\mathrm{c}}$ \\
\hline \multicolumn{3}{|l|}{$\begin{array}{l}\text { Abdominal } \\
\text { skin }\end{array}$} \\
\hline $2(\mathrm{hr})$ & $210.6 \pm 13.53$ & $91.8 \pm 8.83^{\mathrm{c}}$ \\
\hline 7 & $168.4 \pm 16.40^{\mathrm{b}}$ & $72.4 \pm 7.83^{\mathrm{c}}$ \\
\hline 15 & $132.6 \pm 12.17^{\mathrm{b}}$ & $56.8 \pm 6.59^{c}$ \\
\hline 24 & $113.3 \pm 12.27^{\mathrm{b}}$ & $25.6 \pm 3.79^{c}$ \\
\hline \multicolumn{3}{|l|}{$\begin{array}{l}\text { Abdominal } \\
\text { muscle }\end{array}$} \\
\hline $2(\mathrm{hr})$ & $184.4 \pm 6.52$ & $103.4 \pm 14.60^{\mathrm{c}}$ \\
\hline 7 & $110.3 \pm 6.35$ & $72.6 \pm 9.52^{\mathrm{d}}$ \\
\hline 15 & $77.1 \pm 10.81$ & $46.0 \pm 10.70$ \\
\hline 24 & $64.8 \pm 9.72$ & $23.2 \pm 4.71^{\mathrm{d}}$ \\
\hline
\end{tabular}

Five female Sprague-Dawley rats were used in each group and administered orally in a dose of $10 \mu$ moles/ $\mathrm{kg}$ of ${ }^{3} \mathrm{H}$-labeled colors (Mean values \pm S.E.) Significantly different from abdominal muscle ( ${ }^{\mathrm{P}} \boldsymbol{P}<0.01,{ }^{\mathrm{b}} \boldsymbol{P}<0.05$ )

Significantly different from Benzyl Violet 4B $\left({ }^{c} P<0.01,{ }^{\mathrm{d}} P<0.05\right)$ 
Table 2. Biliary Excretion of ${ }^{3} \mathrm{H}-\mathrm{Benzyl}$ Violet $4 \mathrm{~B}$ and ${ }^{3} \mathrm{H}-\mathrm{Fast}$ Green FCF in Rats (p.o.)

\begin{tabular}{|c|c|c|c|c|}
\hline \multirow{2}{*}{$\begin{array}{l}\text { Time after } \\
\text { administration }(\mathrm{hr})\end{array}$} & \multicolumn{2}{|c|}{${ }^{3} \mathrm{H}$-Benzyl Violet $4 \mathrm{~B}$} & \multicolumn{2}{|c|}{${ }^{3} \mathrm{H}$-Fast Green FCF } \\
\hline & $\begin{array}{l}\% \text { Dose } \\
\text { excreted } / \mathrm{hr}\end{array}$ & $\begin{array}{l}\text { Cumulative } \% \\
\text { dose excreted }\end{array}$ & $\begin{array}{l}\% \text { Dose } \\
\text { excreted } / \mathrm{hr}\end{array}$ & $\begin{array}{l}\text { Cumulative } \% \\
\text { dose excreted }\end{array}$ \\
\hline 1 & 0.15 & 0.15 & 0.11 & 0.11 \\
\hline 2 & 0.37 & 0.52 & 0.36 & 0.47 \\
\hline 3 & $0.37^{-}$ & 0.89 & 0.29 & 0.76 \\
\hline 4 & 0.37 & 1.26 & 0.26 & 1.02 \\
\hline 5 & 0.34 & 1.60 & 0.19 & 1.21 \\
\hline 6 & 0.26 & 1.86 & 0.18 & 1.39 \\
\hline 7 & 0.20 & 2.06 & 0.17 & 1.56 \\
\hline 24 & 0.17 & 4.26 & 0.13 & 3.81 \\
\hline
\end{tabular}

Two female Sprague-Dawley rats were used in each group and administered orally in a dose of $10 \mu$ moles $/ \mathrm{kg}$ of ${ }^{3} \mathrm{H}$-labeled colors.

orally to rats $(200 \mathrm{mg} / \mathrm{rat})$ were scarcely absorbed and recovered in excess of $90 \%$ from feces, except for Green No. 2 of which only $68 \%$ was recovered. From the biliary excretion studies of these colors in dogs and rats, they observed that less than $5 \%$ of the administered dose was absorbed and subsequently excreted to the intestine through the bile.

In the previous paper, we improved the twowavelength photometric method to determine Guinea Green $B^{6)}$ and Benzyl Violet $4 B^{5)}$ in tissues, and investigated the absorption, excretion and distribution of these colors in rats. Because of a poor absorption of these colors, the distribution in various tissues was investigated by intravenous administration of a large dose $(100 \mu$ moles $/ \mathrm{kg})$.

In this study, the distribution of ${ }^{3} \mathrm{H}$-labeled colors was studied by oral administration of a small dose $(10 \mu$ moles $/ \mathrm{kg})$. The levels of colors in the ear and the portion of abdominal skin near the site of tumor development, ${ }^{3), 4)}$ and those in the plasma and abdominal muscle apart from tumor developing site were compared.

The results are shown in Table 1 . In the case of Benzyl Violet 4B, the levels of color in the ear and abdominal skin (except at $2 \mathrm{hr}$ ) were significantly higher than those of the abdominal muscle apart from the site of tumor development. These results were essentially similar to the patterns of distribution after intravenous administration in the previous paper. ${ }^{\text {) }}$ On the other hand, in the case of Fast Green FCF, for which there was no gross evidence of
Table 3. Half-lives ${ }^{\mathrm{a}}$ of ${ }^{3} \mathrm{H}-\mathrm{Benzyl}$ Violet $4 \mathrm{~B}$ and ${ }^{3} \mathrm{H}$-Fast Green $\mathrm{FCF}$ in Some Tissues in Female Sprague-Dawley Rats after Oral Administration of the Labeled Colors

\begin{tabular}{|c|c|c|}
\hline \multirow{2}{*}{ Tissue } & \multicolumn{2}{|c|}{ Half-lives in tissue $(\mathrm{hr})$} \\
\hline & $\begin{array}{l}{ }^{3} \mathrm{H}-\text {-Benzyl } \\
\text { Violet 4B }\end{array}$ & $\begin{array}{c}{ }^{3} \mathrm{H}-\mathrm{Fast} \text { Green } \\
\text { FCF }\end{array}$ \\
\hline Plasma & $12.38 \pm 1.71$ & $6.59 \pm 0.12^{\mathrm{c}}$ \\
\hline Ear & $36.15 \pm 3.96^{\mathrm{a}}$ & $11.44 \pm 0.67^{b}$ \\
\hline $\begin{array}{l}\text { Abdominal } \\
\text { skin }\end{array}$ & $38.05 \pm 6.33$ & $12.05 \pm 0.39^{b}$ \\
\hline $\begin{array}{l}\text { Abdominal } \\
\text { muscle }\end{array}$ & $21.37 \pm 1.87$ & $10.15 \pm 0.90^{\mathrm{b}}$ \\
\hline
\end{tabular}

The conditions were the same as in Table 1 . a) Half-lives were calculated from the data of 7,15 and $24 \mathrm{hr}$ in Table 1.

Significantly different from abdominal muscle (a $P<0.05$ )

Significantly different from Benzyl Violet 4B $\left({ }^{\mathrm{b}} P<0.01,{ }^{\mathrm{c}} P<0.05\right)$

tumor development in rats by oral administration $^{7)}$ except the production of fibrosarcomas at the site of subcutaneous injection of the color, ${ }^{8), 8)}$ there was no significant difference between these tissues. Furthermore, the levels of Benzyl Violet 4B in the tissues were higher than those of Fast Green FCF at any time tested.

Table 2 shows the biliary excretion of ${ }^{3} \mathrm{H}$ Benzyl Violet $4 \mathrm{~B}$ and ${ }^{3} \mathrm{H}-\mathrm{Fast}$ Green FCF in the rats administered orally with the labeled colors $(10 \mu$ moles $/ \mathrm{kg})$. The cumulative amounts were 4.26 and $3.81 \%$ of the dose by $24 \mathrm{hr}$ respectively. The maximum excretion was observed 
between 2 and $4 \mathrm{hr}$ for Benzyl Violet $4 \mathrm{~B}$ and at $2 \mathrm{hr}$ for Fast Green FCF, and followed by a gradual decrease. In the case of a large dose of non-labeled Benzyl Violet 4B $(68.1 \mu$ moles $/ \mathrm{kg}$ or $50 \mathrm{mg} / \mathrm{kg}$ ), the cumulative amount was only $0.89 \%$ of the dose at $24 \mathrm{hr}^{5}{ }^{5}$ Therefore, it was suggested that the ratio of absorption of Benzyl Violet $4 \mathrm{~B}$ in a small dosage was higher than that in a large dosage. There was no significant difference between both colors in the biliary excretion.

Table 3 shows the biological half-lives for Benzyl Violet 4B and Fast Green FCF in the tissues of female Sprague-Dawley rats after oral administration of the colors.

The biological half-lives of Benzyl Violet 4B in plasma and other tissues were significantly longer than that of Fast Green FCF. It was noticeable that the biological half-lives in the oral administration was longer than in the intravenous administration. ${ }^{5)}$

From the results of this study and the previous paper, ${ }^{5)}$ the accumulating amount and retaining period of Benzyl Violet 4B in tissues might well be taken in consideration as a possible factor of tumor development, although tumor formation in rats by long-term feeding of the color seems to be influenced by other complicating factors.

\section{References}

1) Hess, S. M., Fitzhugh, O. G.: J. Pharmacol. Exp. Ther., 114, 38 (1955).

2) Iga, T., Awazu, S., Nogami, H.: Chem. Pharm. Bull., 19, 273 (1971).

3) Uematsu, K., Miyaji, T.: J. Natl. Cancer Inst., 51, 1337 (1973).

4) Ikeda, Y., Horiuchi, S., Imoto, A., Kodama, Y., Aida, Y., Kobayashi, K.: Toxicology, 2, 275 (1974).

5) Minegishi, K., Yamaha, T.: ibid., 7, 367 (1977).

6) Minegishi, K., Yamaha, T.: Chem. Pharm. Bull., 22, 2042 (1974).

7) Hansen, W. H., Long, E. L., Davis, K. J., Nelson, A. A., Fitzhugh, O. G.: Fd. Cosmet. Toxicol., 4, 389 (1966).

8) Nelson, A.A., Hagan, E.C.: Fedn Proc. Fedn Am. Socs exp. Biol., 12, 397 (1953).

9) Nelson, A. A., Davidow, B.: ibid., 16, 367 (1957). (Correction: ibid., 16, 661 (1957)). 